\title{
First report of Rhizoctonia solani AG-1 IB causing crown rot on Achillea millefolium in Italy
}

\author{
Angelo Garibaldi ${ }^{1} \cdot$ Giulia Tabone $^{1} \cdot$ Domenico Bertetti $^{1} \cdot$ Maria Lodovica Gullino $^{1}$
}

Received: 23 December 2020 / Accepted: 26 February 2021 / Published online: 22 March 2021

(c) Società Italiana di Patologia Vegetale (S.I.Pa.V.) 2021

Keywords Ornamental plants $\cdot$ Anastomosis group (AGs) $\cdot$ Soil-borne pathogens

In September 2020, symptoms of stunted growth, leaf withering and crown rot were observed on 15 of 40 2-month-old plants of Achillea millefolium (Asteraceae family) grown in 2-L pots in an experimental greenhouse at the Centre of Competence Agroinnova of the University of Torino, located in Grugliasco (Torino, Northern Italy). Plants died 15 days after and colonies with the characteristics of Rhizoctonia solani (Sneh et al. 1991) were consistently isolated. Colonies grown on potato dextrose agar (PDA) for 15 days showed a coarse and light-brown mycelium. Spherical or subspherical dark-brown sclerotia ( 0.1 to $1 \mathrm{~mm}$ in diameter), often confluent, developed after seven days. The isolate 20/52 of $R$. solani was paired with isolates belonging to the subgroup AG-1, AG-2, AG-4, AG-7 and AG-11. The isolate 20/52 anastomosed with $R$. solani AG-1 (ATCC 58,946) with a low fusion frequency $(<30 \%)$. Mycelium and sclerotia were typical for AG-1 IB. A PCR was carried out for the ITS region (GenBank Accession No. MW369685) and results analyzed with BLASTn showed $100 \%$ homology with $R$. solani AG-1 IB (MT177236). Three-month-old plants of $A$. millefolium grown in greenhouse at $22-25{ }^{\circ} \mathrm{C}$ in $2-\mathrm{L}$ pots containing a disinfested peat substrate were used for the pathogenicity test. The inoculum of the isolate 20/52 grown on infested wheat kernel was placed, at a concentration of $2 \mathrm{~g} / \mathrm{L}$, at the basis of three healthy plants. Three plants inoculated with non-infested wheat kernels were used as controls. Plants were maintained in a greenhouse at $22-25^{\circ} \mathrm{C}$.
Four days after the inoculation, the symptoms previously described appeared on the inoculated plants that died seven days after, while control remained healthy. The inoculated pathogen was consistently recovered from the infected tissues. The pathogenicity test was carried out twice, obtaining the same results. $R$. solani was previously reported on $A$. millefolium in USA and Greece (Farr and Rossman 2020). This is the first report of $R$. solani AG-1 IB in Italy on this host. A. millefolium is used as garden and flowering plant and for cut flower production. It is also employed in medicine for its curative properties. The appearance of $R$. solani on A. millefolium could represent a serious problem in Italy where this species is very commonly grown by following the rules of organic farming.

\section{Reference}

Farr DF, Rossman AY (2020) Fungal Databases, U.S. National Fungus Collections, ARS, USDA. Retrieved 14 Dec 2020

Sneh B, Burpee L, Ogoshi A (1991) Identification of Rhizoctonia species. APS, St Paul, MN

Publisher's Note Springer Nature remains neutral with regard to jurisdictional claims in published maps and institutional affiliations.

Giulia Tabone

giulia.tabone@unito.it

1 Centre of Competence for the Innovation in the Agro-Environmental Sector (AGROINNOVA), University of Torino, Largo Paolo Braccini 2, 10095 Grugliasco, Torino, Italy 